\title{
IAMJ
}

INTERNATIONAL

AYURVEDIC

MEDICAL JOURNAL

\section{STHANIK CHIKITSA (LOCAL THERAPIES) IN STRI ROGA: CRITICAL REVIEW}

\author{
$\underline{\text { Simran }}^{1}, \underline{\text { Shashi Sharma }}^{2}, \underline{\text { Shikha Sharma }}^{3}$ \\ ${ }^{1} \mathrm{PG}$ scholar, ${ }^{2} \mathrm{HOD}$ and Reader, ${ }^{3}$ Lecturer \\ P.G. Department of Prasuti Tantra \& Stri Roga, SAC, Lucknow, Uttar Pradesh, India
}

Corresponding Author: simmi00.sk@gmail.com

https://doi.org/10.46607/iamj2409072021

(Published Online: July 2021)

Open Access

(C) International Ayurvedic Medical Journal, India 2021

Article Received: 24/06//2021 - Peer Reviewed: 25/06/2021 - Accepted for Publication: 06/07/2021

\section{Check for updates}

\begin{abstract}
Ayurveda is one of the oldest systems of health gives a detail description of Stree Roga. Women combat with quite common gynecological problems like white discharge, itching at vulva, foul smelling vaginal discharge, burning micturition etc. Sthanik Chikitsa has given excellent results in these problems. Sthanik Chikitsa preferably includes Yonidhawan (Douching per vaginum), Yoni-Pichu (Tampooning per vaginum), Yoni Dhoopan (Fumigation of vagina), Yoni-Varti (Vaginal suppository), Yoni-Lepana (Vaginal painting), Uttarbasti (Medicated oil or decoction is pushed into the uterine cavity through vagina), Agnikarma (Cauterization) and Ksharakarma (Chemical cauterization) etc. In the present study all these local therapies are revised through ancient Samhitas, and these therapies are reviewed with their meanings, indications, procedures, application site and probable mode of actions. It is my sincere and optimistic effort to encourage most of the Ayurveda physician towards Sthanik Chikitsa in the management of Stree Rogas.
\end{abstract}

Keywords: Sthanikchikitsa, Local therapies, Stree Roga.

\section{INTRODUCTION}

Women's health is the fulcrum not only for the healthy status for her family but rather to the whole society and to the nation. A girl must pass through different stages and several anatomical and 
physiological changes occur in her body to become a mature woman. At every stage it needs utmost care but due to responsibility of family and other social works she always neglects her health. There are many gynecological problems which usually occur in a female during her reproductive age. Acharya has mentioned Chikitsa in two parts- Abhyantara Chikitsa and Sthanik Chikitsa. "Sthanik Chikitsa" means specific treatment given locally. Sthanik Chikitsa is beneficial when Sthanik Dosh-dushti is more and it gives strength to respective Sthana. These local therapies have proved greatly beneficial in Stree Rogas if performed accurately. For this purpose, this conceptual study is prepared to understand procedure, indications, probable mode of actions, precautions etc. regarding these local procedures.

The Sthanik Chikitsa (local therapies) are described as follows:

1. Yoni-Dhawana (Douching per vaginum)

Dhawana mean cleaning of wound with water or any other medicated preparations. Yoni Dhawana is a procedure of cleaning vagina and vaginal passage with Kwath or any other liquid. ${ }^{1}$

Application Site- Prathamavarta(Vagina). ${ }^{2}$

Duration - 8 days $^{2}$

Time of administration- Rutukala (from 6th to 13th day of menstrual cycle)

Time limit- 1 to $1.5 \mathrm{~min}^{2}$

Drugs used in the form of- Kwatha (Decoction), Oil, Kshirpaka (Medicated milk), Siddhjala (Medicated water).

Indications-

1. Yoni Srava - Yoni Dhawana with decoction of Triphala ${ }^{3}$

2. Yoni Paicchilya - Decoction of Rajavraksadi group of drugs. ${ }^{4}$

3. Yoni Dourgandhya - Decoction of Aragvadhadi group of drugs. ${ }^{5}$

4. Yoni Kandu - Decoction of Guduchi, Triphala, and Danti. ${ }^{6}$

5. Vatajaartvadushti - Decoction of Sarala and Mudgaparni. ${ }^{7}$
6. Pittjaartvadushti - Decoction of Gairika and Nimb. ${ }^{7}$

7. Kaphajartavadushti - Decoction of Lodhra and Tinduka. ${ }^{7}$

Materials - Enema pot, Sterile Catheter, Cotton.

Procedure-

a. All aseptic measures should be ensured before starting procedure.

b. Lithotomy position given to the patient.

c. Lukewarm decoction is filled in enema pot and pot is placed at 5 feet distance and Prathamavarta is washed out by inserting sterile rubber catheter into vagina.

d. Vulva is cleaned and dried with cotton after procedure.

e. Procedure is repeated on the respective days according to the severity of diseases.

f. Oil or Kwatha once used should be discarded.

Probable mode of action - The drugs used for Dhawana are antiseptic, have bactericidal action, wound healing property, alleviates pain. Drugs are absorbed through mucosa and blood circulation of vagina. Bactericidal actions of the drugs prevent bacterial growth and maintain the $\mathrm{pH}$ of vagina.

2. Yonipichu Dharana (Tampooning per vaginum)

Pichu or tamoon is made up of cotton swab of size $2 \times 3 \mathrm{~cm}$ (1 inch), wrapped with gauze piece and tied with long thread. In Yonipichu mostly medicated Kwatha, Ghrita and Taila are used. These preparations have two main functions Shodhana (purification) and Ropana (healing). ${ }^{8}$

Site - Prathamaavarta ${ }^{9}$

Duration of retention of Pichu- 5-6 hours (up to retention of urine)

\section{Indications-}

1. Streeroga

- Vataja Yonivyapada - Guduchyadi Taila Pichu ${ }^{10}$

- Pittaja Yonivyapada - Pachavalkal Siddha Taila Pichu ${ }^{10}$

- Putraghni Yonivyapada - Udumbar Siddha Taila Pichu ${ }^{10}$

2. Garbhini

- Garbhini Paricharya - In $9^{\text {th }}$ month Madhur Aushadh Siddha Taila Pichu ${ }^{11}$ 
- Garbhasrava - Yashtimadhu Ghrita Pichu ${ }^{11}$

- Aparasang - Shatpushpa, Kushtha, Madanphal, Hingu Siddha Taila Pichu ${ }^{11}$

\section{Procedure -}

a. Pichu used for procedure should be autoclaved.

b. Ask the patient to pass urine before procedure.

c. Ask the patient to lie in supine position with knees flexed.

d. Pichu soaked in medicated oil or liquid should be inserted into vagina with index finger of gloved hands.

e. Thread of Pichu should remain outside the vagina so that Pichu can be removed easily.

Probable mode of action - Pichu helps in Lekhana karma and thus removes slough. ${ }^{12}$ Oil used for Pichu strengthens the musculature of vaginal canal along with healing of wound.

\section{Yoni Dhoopan (fumigation of vagina)}

In this therapeutic procedure the medicated smoke is used to sterilize vulva and vagina.

Site- Bahyayoni (outer surface of vagina)

Duration - 3 to 5 minutes.

Dhoopan drugs - Kushta, Guggulu, Agaru, Vacha, Vidanga, Nimba etc.

\section{Indications-}

1. Yonikandu- Fumigation with Haridra and Brahti $^{13}$

2. Shweta Pradara- Fumigation with Sarala, Guggalu, Yava mixed with Ghrita ${ }^{14}$

3. Sutika Paricharya- Fumigation with Kustha, Guggalu, Agara mixed with Ghrita ${ }^{15}$.

\section{Procedure-}

a. Dhoopan chair or stool is prepared for this procedure. It is a stool which is having a hole in its middle.

b. Patient is asked to sit on the stool after voiding the urine.

c. Dhoopan Dravyas are lit and placed in Dhoopan Yantra which is placed below the stool.

d. One has to make sure that Dhoom coming from Dhoopan Dravyas should reach up to the desired part of female genitalia. e. Nadi Dhoopan is another alternate in which Dhoopan Yantra is connected to a pipe through which Dhoom can reach to expected area.

As the procedure goes on the temperature rises and it may lead to burn the genitalia as it is very sensitive part, so proper care should be taken during procedure. Probable mode of action - Fumigation creates an aseptic environment, kills microbes thereby prevent infections. It dilates blood vessels and helps in oxidation of blood. It leads to adequate tissue perfusion and oxygenation. Thus, reduces inflammation, itching and eliminates infection. ${ }^{16}$

\section{Yoni Lepana (Vaginal Painting)}

Lepa means external application. In this procedure paste of drug is applied over affected area. Paste is made by mixing fine powder of drug with water or any other media.

\section{Site-Prathamavarta}

Time limit - up to Lepa dries (3-4 hour)

\section{Indications-}

1. Yoni Arsha- With powder of Tuttha, Gairika, Lodhra, Ela, Rasanjana, Harenu, Pushpakasis, salt mixed with honey ${ }^{17 .}$

2. Vivrutta Yonivyapada - With powder of Palashbeeja and Udambarphala mixed with Tila Taila and honey ${ }^{18 .}$

\section{Procedure-}

a. Affected part should be cleaned.

b. Lepa should be prepared fresh and applied over affected part uniformly.

c. Immediately after drying, Lepa should be removed as it may irritate the skin and can cause rashes or itching.

\section{Yonivarti (Vaginal suppository)}

Vartis (suppositories) which is made by mixing fine powder of drugs, adhesive drugs or binding agents. Varti should be prepared in a size of circumference of index finger and dried in shade. Prepared and well dried Vartis are wrapped in gauze piece and a thread is tied to it.

Duration- For 2-3 hours

\section{Indications-}

1. Kaphaja Yonivyapada- suppository prepared with powdered Yava, Saindhav and Arkaksheer ${ }^{19}$. 
2. Karnini Yonivyapada- suppository prepared with Kustha, Pippali, Arka, rock salt and Aja Mootra $^{19}$

3. Anartava- suppository prepared with Ikshvaku, Danti, Madanphala, Kinva, Yavashooka, and Snuhiksheera ${ }^{20}$

4. Yoni paichhilya- suppository prepared with Kasis, Triphala, Sphatika, Samnga, Lajjalu, Amrasthi, Dhatakipushpa ${ }^{21 .}$

\section{Procedure-}

a. Autoclaved Varti should be used for procedure.

b. Expected part should be cleaned well.

c. Oil smeared Varti should be inserted in such a way that the thread should remain outside.

d. Up to retention period of urine Varti should be kept inside. As soon as urge of urine felt Varti should be removed.

e. Yoni Dhawana with lukewarm water should be done.

f. Varti once used should be discarded.

6. Uttarbasti (Insertion of medicated oil, decoction into Intra Uterine Cavity through vagina)

Basti which is given through Uttarmarga i.e., either through the passages located above or in front part of anus (urethra or vagina) which is routine Basti route is known as Uttarbasti. Basti which possesses superior qualities is also termed as Uttarbasti. ${ }^{22}$ It also points towards urinary bladder of pig or goat which used for inserting medicine into vagina. Now a day's $5 \mathrm{cc}$ syringe attached with cannula is used for insertion

Time of administration- Artavakala ${ }^{23}$ (from 6th to 13th day of menstrual cycle)

\section{Indication of Uttar Basti}

1. Yonivyapada Chikitsa

- Udavarta \& Vatala - Uttarbasti with Traivritasneha ${ }^{24}$

- Arajaska \& Putraghni - Uttarbasti with Ghrita medicated with the Kwath of Kashmari \& Kutaja $^{24}$

2. Aparasang-Sidharathakadi Tail Uttarbasti ${ }^{25}$

3. Tubal disorders
- Tubal block- If block is due to adhesions Kshartaila Uttarbasti is beneficial. ${ }^{26}$

- Hydro-salphinx- Nirgundi Taila, Yashtimadhu Taila, Til Taila are used to manage this inflammatory condition.

4. Endometrial condition- Sneha prepared from Bruhana Dravyas helps in improving endometrial thickness.

5. Cervical erosion- Triphala ghrita, Shatavari ghrita, Phala ghrita are the commonly used.

\section{Quantity and frequency-}

Acharya Sushruta has explained quantity of Kashaya2 prasrita (192 gms), Sneha- 1 Prasrita (96 gms) and for Garbhashya-shodhan, quantity of Sneha should make double i.e., 2 prasrita. ${ }^{27}$

Uttarbasti Yantra- It has two parts Bastiputaka and Netra.

\section{Classical Method of Uttarbasti ${ }^{28}$ -}

a. A woman is asked to lie down on bed in supine position with flexed thighs and elevated knees.

b. Pushpa Netra is inserted in vaginal or urinary passage slowly and with steady hands in the direction of passage.

c. Karnikas (rings) should be introduced, and vaginal orifices pressed properly then bag of Basti should be compressed properly.

d. In 24 hours two, three or four Basti should be given.

e. Then 3 days rest should be given to patient and again procedure should be repeated for three days.

\section{Practical procedure of Uttarbasti-}

a. All routine examination should be done.

b. Snehan at Udar, Uru, Prushta should be done with Vatashamaka tail.

c. Swedan specially Nadisweda on Udar and Prushta pradesh.

d. Patient is asked to lie down on lithotomy.

e. Painting and draping should be done.

f. Vulva and vagina should be cleaned.

g. Proper visualization of cervix by inserting sim's speculum and anterior vaginal wall retractor and catch the lip of cervix with vulsellum. 
h. Uterine sound is inserted to know the position and length of uterus.

i. Medicated Ghrita or oil is taken in 5cc syringe and IUI cannula is attached to its end.

j. Cannula should insert in uterus through cervix and slowly push the medicine in cavity with steady hand. Instruments should be removed.

k. Pichu is placed in vagina for 2 hours.

1. Head low position should be given to patient and rest for half an hour.

m. Hot fomentation is preferred.

n. Repeat this procedure for $3-5$ days.

7. Kshara Karma (Chemical cauterization)

Kshara are the substance that acts as a corrosive agent for any growth when used externally. Kshara karma is said to be superior to any other surgical or parasurgical measures due to its functions like Chedana, Bhedana, Lekhana and Patana karma. It can be applied in a narrowest place and internally where surgical procedures cannot be performed. ${ }^{29}$

\section{Indication}

1. Yoni Arsha (Genital warts) $)^{30}$

2. Cervical erosion ${ }^{31}$

\section{Procedure}

a. Patient is asked to lie on lithotomy position.

b. Vulva and vagina should be cleaned.

c. Cervix is exposed using cusco's speculum.

d. Kshara is applied with a cotton swab stick over the eroded area and kept in contact for 2 minutes.

e. Thereafter Yoni Prakshalana will be done followed by Jatyadi Taila Picchu.

f. Patient is advised to keep the Pichu for approximately 2 hrs.

Probable mode of action - Kshara has Tikshna Guna and Ushna Virya with predominance of Vayu and Teja Mahabhuta. Vayu helps in fast action while Teja produces caustic effect. Kshara (Apamarga, Snuhi) applied on cervical erosion cause death of superficial cells (due to vasoconstriction) regeneration of basal cells (formation of granulation tissue) growth of squamous epithelium in cervical erosion. ${ }^{31}$

\section{Agni Karma (Cauterization)}

Main advantage of the Agnikarma Chikitsa is it prevents the recurrence of the disease and prevention of the infection.

Dahan Upkaran - Pippali, Ajashakrit, Godanta, Shara, Shalaka etc.

\section{Indication -}

1. Yoni Arsha (Genital Warts)

2. Cervical erosion ${ }^{32}$

\section{Procedure -}

a. Patient is asked to lie on lithotomy position.

b. Vulva and vagina should be cleaned.

c. Swarna Shalaka is heated on flame by the help of spirit lamp.

d. Bindu type of Agnikarma is applied over the area.

e. Thereafter Yastimadhu powder mixed with Ghrita is applied over the wound.

Probable mode of action - It increases the blood circulation to affected site so that the necessary oxygen and nutrient materials are supplied, and waste products are removed. Agnikarma works on different Sampraptighatak of disease and thus Sampraptivightan is done by Agnikarma. ${ }^{32}$

\section{CONCLUSION}

Sthanikachikitsa (Local procedures) has proven to be greatly beneficial treatment as Shaman or Shodhan Chikitsa. Specifically, in Stree Roga, it plays a major role as it directly acts on effected area and pathology can be rectified. Different drug forms such as Kwatha, Taila, Ghrita, Dhoom etc. are used but the benefits of these procedures will be more effective when these procedures will be performed in a correct manner under all aseptic precautions. This study will definitely be useful for Ayurveda physician in their practice.

\section{REFERENCES}

1. Yadavji Trikamji Acharya, Narayan Ram Acharya, editors. Sushrutasamhita with Nimbandhasangraha Commentary 7 th ed. Varanasi: Chaukhambha Orientalia, 2002. P.35

2. Jaymala Shirke, editor. Ayurvediya Strirogavigyan, 1st ed. Pune: Tathagat Prakashan 2003 P. 159. 
3. Charak Samhita, Vidyotini Hindi Com. by Pt. Kashinath Shastri, Part-II, Chikitsa Sthana-30/83

4. Kaviraj Ambikadutta Shastri, Sushruta Samhita, PartII, Uttarstahan 38/25

5. Harishastri Paradkar Vaidya, editor. Ashtangahridaya Uttarsthana 7th ed. Varanasi: Chaukhambha Orientalia, 1982. P.900

6. Yoga Ratnakara with Vidyotini Hindi Commentary by Vaidya Laxmipati Sastri; Uttarardha Yonivyapada Chikitsa.

7. K. R. Shrikantha Murthy, editor. Ashtangasangraha Vol. II. Sharirasthan, Chap. 1/30-32

8. Kaviraj Ambikadutta Shastri, editor, Shushruta Samhita, Part-I, Chikitsasthana -1/9

9. Jaymala Shirke, editor. Ayurvediya Strirogavigyan, 1st ed. Pune: Tathagat Prakashan 2003 P.164

10. Charak Samhita, Vidyotini Hindi Com. by Pt. Kashinath Shastri, Part-II, Chikitsasthana30/61,62,108.

11. Charak Samhita, Vidyotini Hindi Comm. by Pt. Kashinath Shastri, Part-I, Sharirsthana-8/32,24,41.

12. Kaviraj Ambikadutta Shastri, editor, Shushruta Samhita, Part-I, Chikitsasthana -1/40

13. Kaviraj Ambikadutta Shastri, Sushruta Samhita, PartII, Uttarstahan 38/27

14. Charak Samhita, Vidyotini Hindi Com. by Pt. Kashinath Shastri, Part-II, Chikitsa Sthana -30/121

15. Kashyap samhita by P.V. Tewari, Sutra Sthana 22/30

16. Vijaypall Shanti, Sthanika chikitsa in Yonivyapada, Yoni Dhupana, Ayurvedline, Published by Dr. Seetharam Prasad, Banglore, 12th edition, 2012, P150 .

17. Astanga Sangraha by Kaviraj Atridev Gupta, Uttarsthana 39/6

18. Sharangdhara Samhita by Dr. Bramhanand Tripathi, Uttarsthana 11/110

19. Charak Samhita, Vidyotini Hindi Com. by Pt. Kashinath Shastri, Part-II, Chikitsa Sthana chap. 30/71,109

20. Bhavaprakash by Khemraj Shri Krishnadas part 2, Yonirogachikitsa 70/23

21. Astanga sangraha by Kaviraj Atridev Gupta, Uttarsthana 39/74

22. Charaka Samhita Siddhisthana 9/50 with Ayurdeva Dipika comm of Chakrapani. In: Yadav T.

23. Charak Samhita, Vidyotini Hindi Com. by Pt. Kashinath Shastri, Part-II, Siddhisthana- 9/62

24. Charak Samhita, Vidyotini Hindi Com. by Pt. Kashinath Shastri, Part-II,Chikitsa Sthana-30/111,101
25. Ambika dutta (2016), Sushruta Samhit, Part-I, Sharirasthana-10/21

26. Effect of Apamarg Kshar Tail Uttarbasti in management of infertility w.s.r. Tubal blockage. https://doi.org/iamj.v6i1.537

27. Kaviraj Ambikadutta Shastri, Sushruta Samhita, PartI, Chikitsasthana -37/106,116

28. Charak Samhita, Vidyotini Hindi Com. by Pt. Kashinath Shastri, Part-II, Siddhisthana -9/70

29. Kaviraj Ambikadutta Shastri, editor, Shushruta Samhita, Part-I, Sutrasthana-11/3, 5.

30. Kaviraj Ambikadutta Shastri, Sushruta Samhita Part-I, Chikitsasthana-6/2

31. Neelam, Management of cervical erosion by Ksharakarma, Journal of Ayurveda, Jan-March 2011, p-21

32. Tiwari Richa, clinical study to evaluate the efficacy of Agnikarma in Karnini w.s.r. to cervical erosion. International Journal of Ayurveda and Pharma Research, 2020, 8(11), 53-58.

\section{Source of Support: Nil \\ Conflict of Interest: None Declared}

How to cite this URL: Simran Sthanik Chikitsa (Local Therapies) In Stri Roga: Critical Review. International Ayurvedic Medical Journal \{online\} 2021 \{cited July 2021\} Available from: http://www.iamj.in/posts/images/upload/1474_1479.pdf 